\title{
Knowledge and attitudes towards Middle East respiratory sydrome-coronavirus (MERS-CoV) among health care workers in south-western Saudi Arabia
}

Ahmed Asaad, ${ }^{1}$ Rehab El-Sokkary, ${ }^{1}$ Mahdi Alzamanan ${ }^{2}$ and Maher El-Shafei ${ }^{1}$

${ }^{1}$ Department of Medical Microbiology, Faculty of Medicine, Zagazig University, Zagazig, Egypt (Correspondence to: Rehab El-Sokkary: rehab_elsokkary@yahoo.com). ${ }^{2}$ College of Medicine, Najran University, Najran, Saudi Arabia.

\begin{abstract}
Background: Saudi Arabia is considered the epicentre of MERS-CoV. Since 2012, a total of 1844 cases of MERS-CoV have been reported. A recent cluster, with 8 cases, has been reported in Najran region in the south-western region of the country. This analysis of data from that region on health care workers (HCWs) awareness and attitudes towards the prevention and control of MERS-CoV may be useful when planning health education programmes about this emerging infectious disease.
\end{abstract}

Aims: We aimed to investigate the knowledge and attitude of HCWs toward MERS-CoV in south-western Saudi Arabia.

Methods: This cross sectional study was conducted on HCWs in primary health care centres and hospitals at Najran. A questionnaire containing 14 knowledge and 8 attitude items was completed by all 870 participants.

Results: Overall, $>80 \%$ of HCWs were aware about MERS-CoV etiology, mode of transmission, risk factors, and signs and symptoms. Knowledge scores revealed $51 \%$ of participants had sufficient knowledge. Physicians and nurses had significantly better knowledge compared with other HCWs $(P=0.001)$. Participants who worked at institutions with established infection control programme scored significantly better on knowledge questions $(P=0.001)$. Concerning attitude, $>70 \%$ of HCWs exhibited a positive attitude toward MERS-CoV.

Conclusion: the HCWs in Najran region showed a high level of knowledge and positive attitude toward MERS-CoV. There was a noticeable difference in knowledge level between different professions. Periodic educational interventions and professional campaigns are still needed. Any interventions should be directed towards the non-physician and non-nursing professions.

Keywords: MERS-CoV; health care workers; knowledge; attitudes, infection control

Citation: Asaad A; El-Sokkary R; Alzamanan M; El-Shafei M. Knowledge and attitudes towards Middle East respiratory syndrome-coronavirus (MERS$\mathrm{CoV}$ ) among health care workers in south-western Saudi Arabia. East Mediterr Health J. 2020;26(4):435-442. https://doi.org/10.26719/emhj.19.079

Received: 19/05/18; accepted: 20/09/18

Copyright $@$ C World Health Organization (WHO) 2020. Open Access. Some rights reserved. This work is available under the CC BY-NC-SA 3.0 IGO license (https://creativecommons.org/licenses/by-nc-sa/3.o/igo).

\section{Introduction}

Two strains of coronavirus have been found to infect humans: severe acute respiratory syndrome-coronavirus, SARS-CoV, and Middle East respiratory syndrome-coronavirus MERS-CoV) (1). In September 2012, the first case of MERS (the index case) was reported in Saudi Arabia. Soon afterwards, a patient from Qatar who had visited Saudi Arabia began experiencing acute respiratory symptoms and renal failure. The symptoms and type of virus described in these 2 patients were similar (2).

As of May 2018, a total of 2220 laboratory-confirmed cases, including 790 deaths (case-fatality rate 35.6\%), have been reported to the World Health Organization (WHO) from a total of 27 countries. The majority of cases have been reported in the Middle East (3). Transmission has most commonly been associated with nosocomial outbreaks (4-8).

Saudi Arabia is considered the epicentre of MERSCoV. Since 2012, a total of 1844 cases of MERS-CoV have been reported, with 716 related deaths and a case-fatality rate of approximately $38.8 \%$ (3). Between January through May 2018, the Ministry of Health reported 75 laboratory confirmed cases with 23 deaths occurring in 4 distinct clusters ( 2 health care and 2 household clusters) in different regions of the country. Among these recent clusters, a household cluster was reported from Najran region with 8 reported cases, and the source of infection is believed to be camels at the initial patient's home $(3,9)$. This epidemiologic pattern poses great public health challenge to the local health authorities and health care sectors in view of the fact that Saudi Arabia traditionally hosts large gatherings such as the Hajj pilgrimage (10-12).

So far, no vaccine has been developed for MERS and no antiviral treatment is specifically recommended. Therefore, applying preventive measures to reduce the spread of the disease is of the utmost importance (13). The WHO and the Centers for Disease Control and Prevention (CDC) have published recommendations for the prevention and control of MERS infection in health care settings (14). This includes hand hygiene, wearing personal protective equipment, and patient placement (15). 
Given the mode of MERS transmission, health care workers (HCWs) in contact with MERS patients are expected to be at a high risk of infections. Previous clinical studies have shown that the seroprevalence of MERS-CoV among HCWs who had had contact with MERS patients ranged from $0.3 \%$ to $20.9 \%$. Therefore, use of personal protective equipment is crucial to reducing transmission. Gowns and gloves are recommended as a contact precaution, and surgical masks are recommended as a droplet precaution (16-19). However, these effective infection prevention and control practices depend on awareness and compliance among HCWs at all levels (15). A poor level of knowledge has been implicated in the rapid spread of the infection in hospitals (18). Despite many previous Saudi Arabian studies examining the knowledge and practices in regard to MERS among HCWs in different regions of the country $(10,11,20,21)$, data from the south-western region are scarce. In addition, HCWs represent a major section of the Saudi Arabian population and constitute a considerable source of infected cases in the country $(16,17)$. Najran region alone has 7 general hospitals and 55 primary health care centres, with a total of $3320 \mathrm{HCWs}$, including 784 physicians and 1842 nurses, according to the Ministry of Health statistics (9).

This study aimed to investigate the knowledge and attitude of HCWs toward MERS infection in southwestern Saudi Arabia. The findings may be useful in recommending any remedial measures and additional interventions in the study area to improve awareness and attitudes among HCWs.

\section{Methods}

\section{Sample}

This cross-sectional, descriptive study of a representative sample of Saudi HCWs (physicians, dentists, pharmacists, nurses and laboratory staff) in primary health care centres and hospitals in Najran, a city in south-western Saudi Arabia, was conducted from June to October 2016. The study was conducted according to the international guidelines of Strengthening the Reporting for Observational Studies in Epidemiology; STROBE (22). The sample size required for the study was estimated to be 685 , based on an average previous estimate of 54\% MERS awareness among Saudi HCWs (10), with an absolute precision of $2 \%$ and at a $95 \%$ confidence interval. To avoid loss of participants, a total sample of $870 \mathrm{HCWs}$ was included in the present study. A stratified proportional allocation random sample was used. The stratification factors taken into consideration were the age, sex, type of health care speciality and relative number and type of health care facility.

The study followed the principles of the Helsinki Declaration and ethical approval was obtained from the ethics and research committee of Najran University. Written consent was obtained from all participants.

\section{Questionnaire interview}

A standardized questionnaire was distributed and completed by all participants inside their health care facilities (primary health care centres and hospitals) during the first 2-month period of the study. The self-administered questionnaire was developed, with some modifications, using the frequently asked questions from the WHO and the Saudi Ministry of Health websites $(9,23)$.

The questionnaire was initially designed in English and translated into Arabic by experts in infectious diseases and biostatistics to match with the local colloquial Arabic terminology used by physicians and health educators in the community. After translation and back translation (24), the questionnaire was pilot tested on $20 \mathrm{HCWs}$ (7 doctors, 6 nurses and 13 technicians) who are not included among the study participants to determine acceptability and the clarity of the questions, and to confirm its face validity; it was then modified accordingly.

The questionnaire comprised 3 parts addressing knowledge and attitude of HCWs regarding MERS. The first part covered demographic data such as age, sex, current job and participants' source of knowledge on MERS (6items). The second part assessed the knowledge of HCWs by asking questions about the etiology, incubation period, symptoms, risk group, consequences, source of transmission, prevention and treatment of MERS (11 items). A scoring system was applied to assess the level of knowledge of each subject, as has been previously used (with some modifications) (11): 2 points for each correct answer, 1 point for an incorrect answer. A total of $\geq 12$ points ( $\geq 60 \%$ of total marks) was considered sufficient knowledge. Participants were grouped into 2 categories according to their level of knowledge: insufficient $(<12$ points), and sufficient ( $\geq 12$ points). The third part of the questionnaire assessed the attitude of HCWs regarding MERS using a set of 8 yes/no questions.

\section{Statistical analysis}

Data were coded, validated and analysed using SPSS, version 22. Frequencies and proportions were used to present the data. Chi-squared was used as the test of significance at the $5 \%$ level.

\section{Results}

A total of 820 HCWs completed the questionnaire, a response rate of $94.3 \%$. The age range of the participants was $23-58$ years, median (IQR) $31(28-38)$ years and mean 33.7 (standard deviation 8.6) years. Table 1 shows the baseline characteristics of the respondents. More than twothirds (563) were male. The study group included 200 (24.4\%) nurses, $185(22.6 \%)$ physicians and 435 (53.0\%) other HCWs; 132 (71.4\%) physicians and 124 nurses worked in primary health care centres. More than half of the respondents $476(58 \%)$ perceived that they had sufficient knowledge about MERS. The main sources of MERS information were the Ministry of Health website 410 (50.0\%) and social media 296 (36.1\%).

Table 2 shows the current status of MERS knowledge among HCWs. The majority, 762 (92.9\%), were aware that the disease is a viral infection, $748(91.2 \%)$ were familiar with its mode of transmission and $688(83.9 \%)$ with the signs and symptoms. A majority of participants agreed 


\begin{tabular}{lc}
\hline $\begin{array}{l}\text { Table } 1 \text { Baseline characteristics of health care workers, } \\
\text { Najran, 2016 }\end{array}$ \\
$\begin{array}{l}\text { Pharacteristic } \\
\text { (n = 820) } \\
\text { No. (\%) }\end{array}$ \\
Sex \\
$\quad$ Male \\
Female & $563(68.7)$ \\
Age (years) & $257(31.3)$ \\
21-30 & \\
$31-40$ & $338(41.2)$ \\
$41-50$ & $326(39.8)$ \\
50 & $120(14.6)$ \\
Occupation & $36(4.4)$ \\
Nurse & \\
Physician & $200(24.4)$ \\
Pharmacist & $185(22.6)$ \\
Technician & $148(18)$ \\
Dentist & $105(12.8)$ \\
Laboratory worker & $102(12.4)$ \\
Doyou have sufficient knowledge about MERS-CoV? & $60(7.3)$ \\
Yes & \\
No & $476(58.0)$ \\
Don't know & $322(39.3)$ \\
Mource of knowledge about MERS-CoV & $22(2.7)$ \\
Social media & \\
Newspaper & $410(50.0)$ \\
TV & $296(36.1)$ \\
\hline & $72(8.8)$ \\
& $42(5.1)$ \\
\hline
\end{tabular}

that patients with chronic diseases [760 (92.7\%)] and HCWs [692 (84.4\%)] are at a higher risk of infection. However, the participants' knowledge about questions related to MERS vaccination, treatment by antibiotics, diarrhoea as a possible symptom, and the incubation period was poor.

The knowledge scores were correlated against the baseline characteristics of the respondents (Table 3). Females had statistically significantly better knowledge than males $(P=0.002)$. Sufficient knowledge was significantly correlated with age $(P=0.001)$. Moreover, physicians and nurses had significantly better knowledge compared with other HCWs $(P=0.001)$. As expected, HCWs at institutions with established infection control programmes scored significantly better $(P=0.001)$.

Over $70 \%$ of HCWs exhibited a positive attitude toward MERS. The majority of participants (79\%) knew that MERS infection could be prevented by using isolation and standard precautions. Besides, $88.4 \%$ felt that the information in Saudi society was sufficient to deal with MERS and 95.7\% that their institutions would be able to control any emerging MERS epidemic (Table 4).

\section{Discussion}

Currently, MERS is a daily discussion topic in the media and among the public, especially among patients and HCWs. This analysis of data from south-western Saudi Arabia tries to inform on awareness and attitudes towards the prevention and control of MERS among HCWs: our findings may be useful when planning health education programmes about this emerging infectious disease.

We found that $50 \%$ of the participants depended on the Ministry of Health website as a main source of information about MERS. This differs from the findings of previously published studies, where social media and television were the main sources of information (11,13,1921,25). This indicates that the educational materials posted online by the Ministry of Health encouraged the busy HCWs to use them. At the same time, it sets a great responsibility on health care authorities to increase the accessibility of such materials by varying the means of information delivery, aiming to improve knowledge levels. A finding of considerable concern is that $36 \%$ of HCWs used social media as a source of information. Because of the difficulty in determining the validity and scientific content of information sources as well as the possibility of misinformation being presented, HCWs should practice careful evaluation of MERS-related educational materials (1).

The findings of this study suggest a good relationship between information available in the media about MERS and the depth of knowledge among HCWs. For example, about $97 \%$ of the participants knew about the preventive measures, $92.9 \%$ about the causative agent of the disease, $91 \%$ about the mode of transmission, and $83.9 \%$ about the clinical symptoms. These results are consistent with findings from previous studies $(11,13,25,26)$. On the other hand, fewer participants were knowledgeable about diarrhoea as a symptom of disease, vaccine availability and the incubation period.

As per CDC recommendations, Saudi Arabia has led the relevant authorities to initiate educational campaign targeted towards HCWs. These mainly focused on the prevention, treatment and symptoms of MERS $(9,15)$. Nevertheless, greater encouragement is needed for HCWs to refer to the Ministry of Health websites.

In this study, only $51 \%$ of participants had sufficient knowledge about MERS. Such unsatisfactory results highlight the need for greater efforts to raise general awareness among HCWs about MERS. As expected, age was significantly associated with higher proportions of sufficient knowledge. A number of previous studies also found that older HCWs showed higher rates of knowledge and awareness $(11,20,27)$.

We found that there was variability among HCWs in their knowledge level. For example participants who worked in places where a preventive programme and infection control policies are applied had greater levels of sufficient knowledge than those working in places without an infection control programme. Physicians 


\begin{tabular}{lc}
\hline Table 2 Knowledge about MERS-CoV among health care workers, Najran, 2016 & Correct answer \\
Question (correct answer) & No. (\%) \\
MERS-CoV is a viral infection (Yes) & $762(92.9)$ \\
MERS-CoV is transmitted by close contact with infected person or animal (Yes) & $748(91.2)$ \\
Fever, cough and shortness of breath are symptoms of MERS (Yes) & $688(83.9)$ \\
Diarrhoea is a possible symptom of MERS (Yes) & $504(61.5)$ \\
The incubation period is 2-4 weeks (No) & $484(59.0)$ \\
MERS-CoV vaccine is available in markets (No) & $564(68.8)$ \\
Antibiotics are the first-line treatment (No) & $588(71.7)$ \\
Washing hands with soap and water can help in prevention of disease transmission (Yes) & $796(97.1)$ \\
Patients with underlying chronic diseases are at a higher risk of infection (Yes) & $760(92.7)$ \\
Health care workers are at a higher risk of infection (Yes) & $692(84.4)$ \\
MERS could be fatal (Yes) & $666(81.2)$
\end{tabular}

\begin{tabular}{|c|c|c|c|c|}
\hline Characteristic & $\begin{array}{l}\text { Sufficient knowledge } \\
\qquad(n=416) \\
\text { No. }(\%)\end{array}$ & $\begin{array}{l}\text { Insufficient knowledge } \\
\qquad \begin{array}{c}(n=404) \\
\text { No. }(\%)\end{array}\end{array}$ & $\begin{array}{c}\text { Total } \\
(\mathbf{n}=\mathbf{8 2 0})\end{array}$ & $P$-value \\
\hline \multicolumn{5}{|l|}{ Sex } \\
\hline Male & $216(38.4)$ & $247(60.7)$ & 463 & 0.002 \\
\hline Female & $200(77.8)$ & $57(22.2)$ & 257 & \\
\hline \multicolumn{5}{|l|}{ Age (years) } \\
\hline $21-30$ & $84(24.9)$ & $254(75.1)$ & 338 & 0.001 \\
\hline $31-40$ & $214(50.2)$ & $112(48.8)$ & 326 & \\
\hline $41-50$ & $96(80)$ & $24(20)$ & 120 & \\
\hline$>50$ & $26(72.2)$ & $10(27.8)$ & 36 & \\
\hline \multicolumn{5}{|l|}{ Occupation } \\
\hline Nurse & $158(79)$ & $42(21)$ & 200 & \\
\hline Physician & $146(78.9)$ & $39(21.1)$ & 185 & 0.001 \\
\hline Pharmacist & $70(47.3)$ & $78(52.7)$ & 148 & \\
\hline Dentist & $6(5.9)$ & $96(94.1)$ & 102 & \\
\hline Technician & $36(34.3)$ & $69(65.7)$ & 105 & \\
\hline Laboratory worker & 0 & $60(100)$ & 60 & \\
\hline \multicolumn{5}{|l|}{ Presence of animals } \\
\hline Yes & $124(58.5)$ & $88(41.5)$ & 212 & 0.117 \\
\hline No & $292(48.8)$ & $306(51.2)$ & 598 & \\
\hline Don't know & 0 & $10(100)$ & 10 & \\
\hline \multicolumn{5}{|c|}{ Do you have sufficient knowledge about MERS-CoV? } \\
\hline Yes & $324(68.1)$ & $152(31.9)$ & 476 & 0.082 \\
\hline No & $82(25.5)$ & $240(74.5)$ & 322 & \\
\hline Don't know & $10(16.1)$ & $52(83.9)$ & 62 & \\
\hline \multicolumn{5}{|c|}{ Have you had previous contact with MERS patients? } \\
\hline Yes & $76(52.1)$ & $72(47.9)$ & 148 & 0.428 \\
\hline No & $340(53.3)$ & $298(46.7)$ & 638 & \\
\hline Don't know & 0 & $34(100)$ & 34 & \\
\hline \multicolumn{5}{|c|}{ Presence of prevention programme } \\
\hline Yes & $386(88.5)$ & $284(70.3)$ & 670 & 0.001 \\
\hline No & $16(3.8)$ & $36(8.9)$ & 52 & \\
\hline Don't know & $14(3.4)$ & $84(20.8)$ & 98 & \\
\hline
\end{tabular}




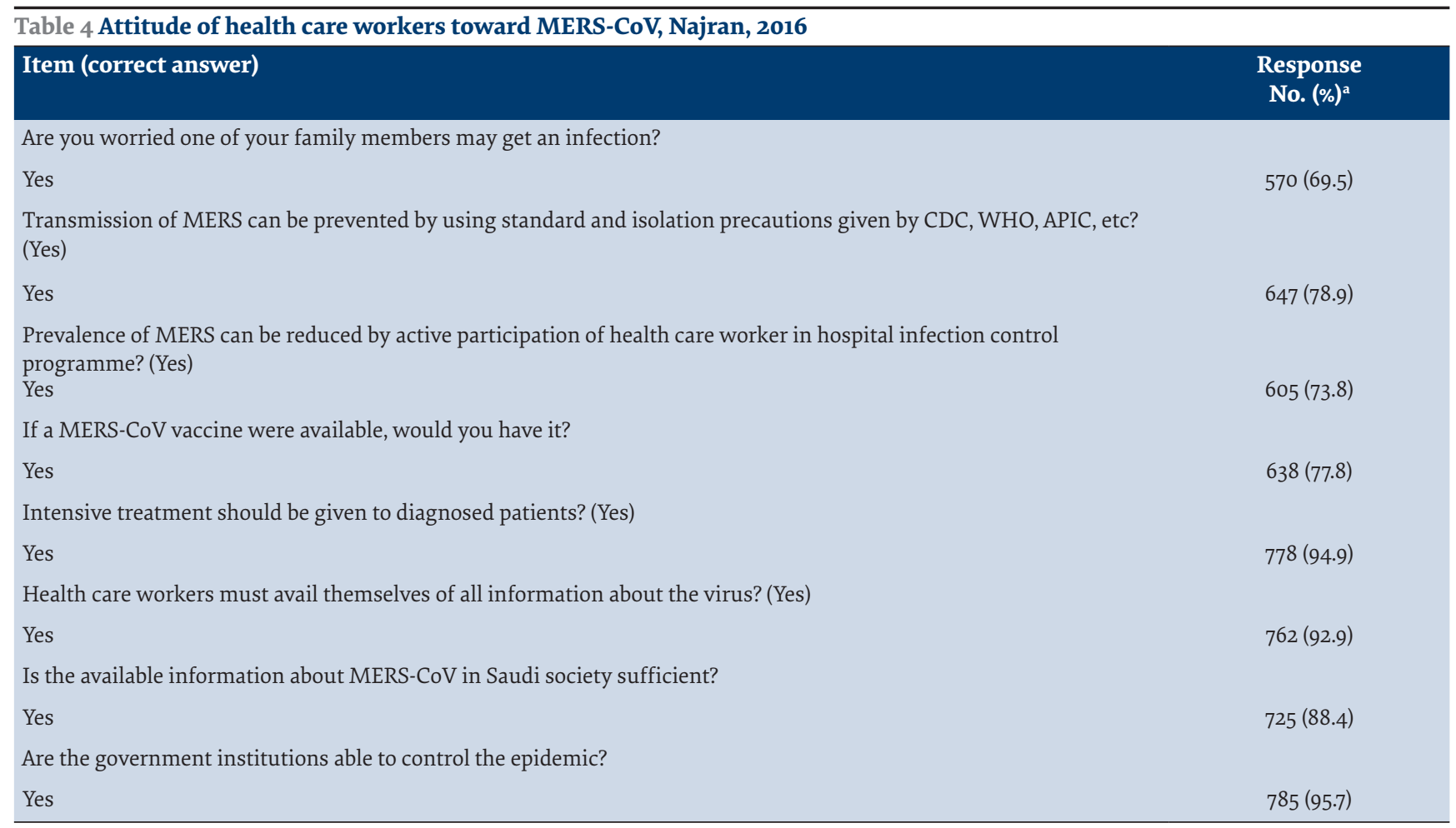

$C D C=$ Centers for Disease Control and Prevention, $W H O=$ World Health Organization, APIC = Association for Professionals in Infection Control and Epidemiology.

${ }^{a}$ All respondents answered either yes or no. There were no missing values or don't know responses.

and nurses had better knowledge levels than other professions, as seen elsewhere $(20,28,29)$. Any upcoming educational programmes could be designed to target those professions which demonstrated a greater incidence of insufficient knowledge level, i.e. in our study this included dentists, pharmacists, technicians and laboratory personnel.

Those HCWs who had previous contact with infected patients showed a high level of insufficient knowledge, which is an unexpected result and points to the importance of health care authorities setting up awareness campaigns for patient contacts which also include their managing health team.

Generally, most participants had a positive attitude towards active participation in infection control programmes and the role of guidelines in prevention of the infection. They believed in the ability of the government to control an epidemic. However, 22.2\% showed negative attitudes towards vaccination. This could be explained by a lack of proper knowledge about the preventive role of active immunization.

Although the majority of respondents were not able to determine their actual knowledge level, about 93\% believe that HCWs must avail themselves of all information about the virus. The majority agreed that patients infected with MERS should be intensively treated. Moreover, almost $70 \%$ of our participants were worried about MERS infection for their family. Similar findings have been reported in many previous studies $(20,26,27)$.
This study had some limitations. Firstly, the questionnaire data may have been subject to recall bias and misclassification. However, we can expect that HCWs have the necessary medical knowledge to correctly respond to all items of the questionnaire tool. Secondly, our study was limited to the south-western region of Saudi Arabia, thus the results presented here may not be generalizable to the rest of the country. Finally, the lack of detailed information about the attitude of HCWs towards MERS is a potential limitation. Therefore, carrying out further large-scale studies from other regions in Saudi Arabia is important to further explore awareness and attitude of HCWs at the national level.

\section{Conclusion}

The HCWs in Najran region showed a high level of knowledge and positive attitudes towards MERS. However, there is a noticeable difference in knowledge level between the professions. Periodic educational interventions using locally-adjusted methods are indicated as these could contribute to improving any deficiencies in knowledge, e.g. the incubation period, and diarrhoea as a possible symptom. Greater educational efforts about prevention should be directed to dentists, technicians, pharmacists and laboratory workers, and patient contacts (including the treating team) should be more involved in the process of education about infectious diseases.

\section{Funding: None.}

Competing interests: None declared. 


\section{Connaissances et attitudes vis-à-vis du coronavirus du syndrome respiratoire du Moyen-Orient (MERS-CoV) parmi les agents de santé dans le sud-ouest de l'Arabie saoudite}

\section{Résumé}

Contexte : L'Arabie saoudite est considérée comme étant l'épicentre du MERS-CoV. Depuis 2012, un total de 1844 cas de MERS-CoV ont été déclarés. Récemment, un groupe de huit cas a été notifié dans la région de Najran dans le sud-ouest du pays. La présente analyse des données de cette région portant sur le niveau de sensibilisation et les attitudes des agents de santé vis-à-vis de la lutte contre le MERS-CoV et de sa prévention peut être utile dans le cadre de la planification des programmes d'éducation sanitaire concernant cette maladie infectieuse émergente.

Objectifs : Notre objectif était d'examiner les connaissances et les attitudes des agents de santé vis-à-vis du MERS-CoV dans le sud-ouest de l'Arabie saoudite.

Méthodes : La présente étude transversale a été menée auprès d'agents de santé dans les centres de soins de santé primaires et les hôpitaux de Najran. Un questionnaire contenant 14 items sur les connaissances et 8 items sur les attitudes a été rempli par les 870 participants.

Résultats: Globalement, plus de $80 \%$ des agents de santé avaient des connaissances sur l'étiologie, le mode de transmission, les facteurs de risque ainsi que sur les signes et les symptômes du MERS-CoV. Les scores de connaissance ont montré que $51 \%$ des participants avaient un niveau suffisant. Les médecins et les personnels infirmiers présentaient un niveau de connaissance significativement plus élevé que les autres aux agents de soins de santé $(p=0,001)$. Les participants qui travaillaient dans des institutions dotées d'un programme de lutte contre les infections bien établi obtenaient des scores significativement plus élevés aux questions portant sur les connaissances $(p=0,001)$. S'agissant des attitudes, plus de $70 \%$ des agents de santé ont montré une attitude positive vis-à-vis du MERS-CoV.

Conclusion : les agents de santé de la région de Najran faisaient preuve d'un niveau élevé de connaissances et avaient une attitude positive vis-à-vis du MERS-CoV. On a observé une différence non négligeable concernant le niveau de connaissances entre les différentes professions. Des interventions éducatives et des campagnes périodiques à l'intention des professionnels demeurent nécessaires. Toute intervention devrait cibler les membres du personnel soignant qui ne sont ni médecins ni infirmiers.

$$
\begin{aligned}
& \text { معلومات واتجاهات العاملين في مجال الرعاية الصحية تجاه فيروس كورونا المسبب لمتلازمة الثرق الأوسط التنفسية في جنوب غرب } \\
& \text { المملكة العربية السعودية } \\
& \text { أحمد أسعد، رحاب السكري، مهدي الزمانان، ماهر الشافعي } \\
& \text { الخالاصة }
\end{aligned}
$$

الخلفية: تُعدُّ المملكة العربية السعودية بؤرة لفيروس كورونا المسبب لمتلازمة الشرق الأوسطا التنفسية. فمنذ عام 2012، بلغ المّام عدد الحالات الإجمالية

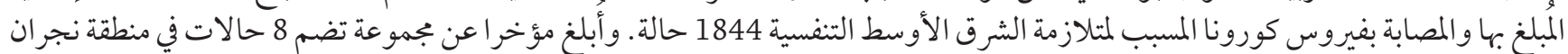

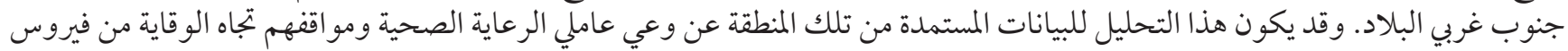

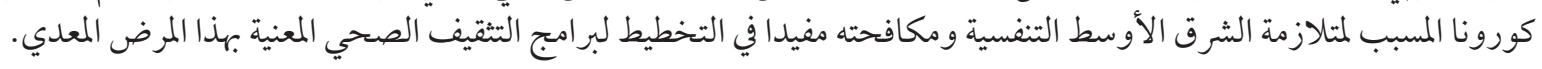
الأهداف: هدفنا استقصاء معلومات واتجاهات العاملين في بجال الرعاية الصحية في جنوب غربي المملكة العربية السعودية نحو فيروس كورونا

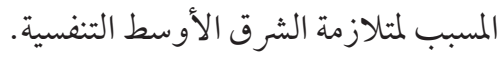

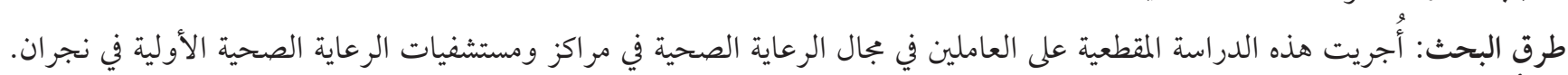

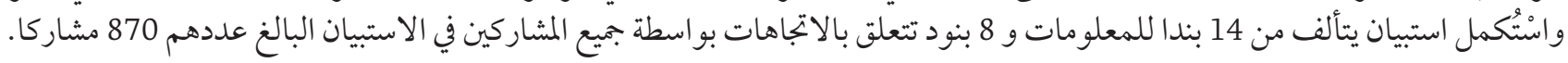

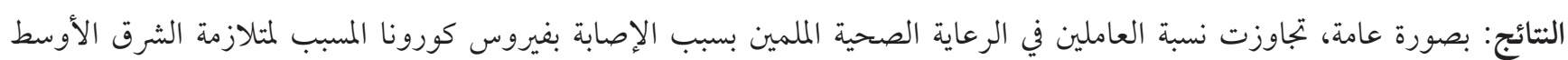

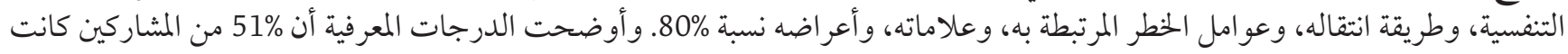

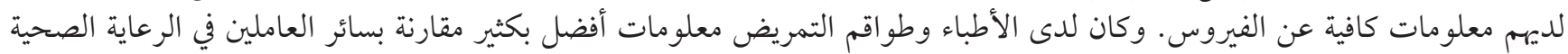

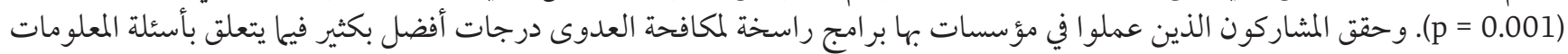

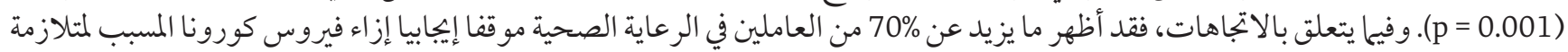
الشرق الأوسط التنفسية.

الاستنتاج: أظهر العاملين في الرعاية الصحية في منطقة نجران مستوى معلومات مرتفعا واتجاهات إيجابية تجاه فيروس كورونا المسبب لمتلازمة

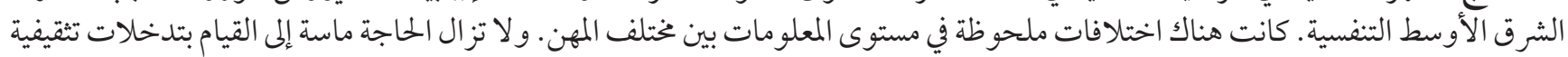

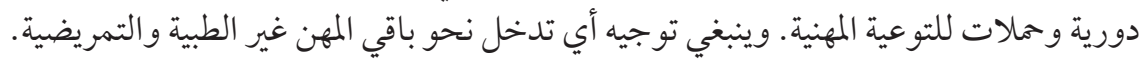




\section{References}

1. Meyer B, García -Bocanegra I, Wernery U, Wernery R, Sieberg A, Müller MA, et al. Serologic assessment of possibility for MERSCoV infection in equids. Emerg Infect Dis. 2015 Jan;21(1):181-2. doi:10.3201/eid2101.141342

2. Zaki AM, Van Boheemen S, Bestebroer TM, Osterhaus AD, Fouchier RA. Isolation of a novel coronavirus from a man with pneumonia in Saudi Arabia. N Engl J Med. 2012:367 (19):1814-20. doi:10.1056/NEJMoa1211721

3. Middle East respiratory syndrome coronavirus (MERS-CoV). Geneva: World Health Organization; 2018 (http://who.int/emergencies/mers-cov/en/, accessed 12 July 2018).

4. Assiri A, McGeer A, Perl TM, Price CS, Al Rabeeah AA, Cummings DA, et al. Hospital outbreak of Middle East respiratory syndrome coronavirus. N Engl J Med. 2013;369(5):407-16. doi:10.1056/NEJMoa1306742

5. Al-Abdallat MM, Payne DC, Alqasrawi S, Rha B, Tohme RA, Abedi GR, et al. Hospital-associated outbreak of Middle East respiratory syndrome coronavirus: a serologic, epidemiologic, and clinical description. Clin Infect Dis. 2014:59:1225-33. doi:10.1093/cid/ ciu359

6. Oboho IK, Tomczyk SM, Al-Asmari AM, Banjar AA, Al-MugtiH, Aloraini MS, et al. 2014 MERS-CoV outbreak in Jeddah - a link to health care facilities. N Engl J Med. 2015:372 (9):846-54. doi:10.1056/NEJMoa1408636

7. Korea Centers for Disease Control and Prevention. Middle East respiratory syndrome coronavirus outbreak in the Republic of Korea. Osong Public Health Res Perspect 2015:6(4):269-78.

8. Park HY, Lee EJ, Ryu YW, Kim Y, Kim H, Lee H, et al. Epidemiological investigation of MERS-CoV spread in a single hospital in South Korea, May to June 2015. Euro Surveill. 2015:20 (25):1-6. doi:10.2807/1560-7917.es2015.20.25.21169

9. FAQs Coronavirus (MERS-CoV). Riyadh: Ministry of Health; 2018 (http://www.moh.gov.sa/en/CCC/FAQs/Corona/Pages/default. aspx/, accessed 12 July 2018).

10. Al-Mohrej OA, Al-Shirian SD, Al-Otaibi SK, Tamim HM, Masuadi EM, Fakhoury HM. Is the Saudi public aware of Middle East respiratory syndrome? J Infect Pub Health. 2016:9(3):259-66. doi:10.1016/j.jiph.2015.10.003

11. Almutairi KM, Al Helih EM, Moussa M, Boshaiqah AE, Saleh Alajilan A, Vinluan JM, et al. Awareness, attitudes, and practices related to coronavirus pandemic among public in Saudi Arabia. Fam Comm Health. 2015:38 (4):332-340. doi:10.1097/ FCH.0000000000000082

12. Schnirring L. Hospital emerges as epicenter of Riyadh MERS outbreak. Minneapolis: Center for Infectious Disease Research and Policy, University of Minnesota; 2015 (http://www.cidrap.umn.edu/news-perspective/2015/o8/hospital-emerges-epicenter-riyadh-mers-outbreak, accessed 5 September 2019).

13. Al-Hazmi A, Gosadi I, Somily A, Alsubaie S, Saeed AB. Knowledge, attitude and practice of secondary schools and university students toward Middle East Respiratory Syndrome epidemic in Saudi Arabia: a cross-sectional study. Saudi J Biolog Sci. 2018;25(3):572-7. https://doi.org/10.1016/j.sjbs.2016.01.032

14. de Groot RJ, Baker SC, Baric RS, Brown CS, Drosten C, Enjuanes L, et al. Middle east respiratory syndrome corona-virus (MERSCoV); announcement of the Coronavirus Study Group. J Virol. 2013:5:13-15. doi:10.1128/JVI.01244-13

15. Interim infection prevention and control recommendations for hospitalized patients with middle east respiratory syndrome coronavirus (MERS-CoV). Atlanta: Centers for Disease Control and Prevention; 2015 (https://www.tn.gov/content/dam/tn/health/ documents/reportable-diseases/middle-east-respiratory-syndrome-mers-cov/CDC-infection-prevention-control.pdf, accessed 5 September 2019).

16. Assiri A, McGeer A, Perl TM, Price CS, Al Rabeeah AA, Cummings DA, et al. Hospital outbreak of Middle East respiratory syndrome coronavirus. N Engl J Med. 2013:369(5):407-16. doi:10.1056/NEJMoa1306742

17. Oboho IK, Tomczyk SM, Al-Asmari AM, Banjar AA, Al-Mugti H, Aloraini MS, et al. 2014 MERS-CoV outbreak in Jeddah - a link to health care facilties. N Engl J Med. 2015:372:846-54. doi:10.1056/NEJMoa1408636

18. Kim SG. Healthcare workers infected with Middle East respiratory syndrome coronavirus and infection control. J Kor Med Assoc. 2015:58:647-54. doi:10.5124/jkma.2015.58.7.647

19. Kim CJ, Choi WS, Jung Y, Kiem S, Seol HY, Woo HJ, et al. Surveillance of the Middle East respiratory syndrome (MERS) coronavirus $(\mathrm{CoV})$ infection in healthcare workers after contact with confirmed MERS patients: Incidence and risk factors of MERS-CoV seropositivity. Clin Microbiol Infect. 2016:22 (10):880-6. doi:10.1016/j.cmi.2016.07.017

20. Khan MU, Shah S, Ahmad A, Fatokun O. Knowledge and attitude of healthcare workers about Middle East Respiratory Syndrome in multispecialty hospitals of Qassim, Saudi Arabia. BMC Pub Health. 2014;14:1281.

21. Kharma MY, Alalwani MS, Amer MF, Tarakji B, Aws G. Assessment of the awareness level of dental students toward Middle East Respiratory Syndrome-coronavirus. J Int Soc Prev Comm Dent. 2015:5 (3):163-9. doi:10.4103/2231-0762.159951

22. STROBE checklist, version 4. Bern: Institute of Social and Preventive Medicine University of Bern; 2007 (http://www. strobe-statement.org/index.php?id=available-checklists, accessed 5 September 2019).

23. World Health Organization. Frequently asked questions on Middle East respiratory syndrome coronavirus (MERS-CoV). Geneva: World Health Organization; 2018 (http://www.who.int/csr/disease/coronavirus_infections/faq/en/, accessed 12 July 2018).

24. Process of translation and adaptation of instruments. Geneva: World Health Organization; 2018 (http://www.who.int/substance_ abuse/research_tools/translation/en/, accessed 12 July 2018). 
25. ALdowyan NM, Ahmed AS, El-Gharabawy RM. Knowledge, Attitude and Practice (KAP) Study about Middle East Respiratory Syndrome Coronavirus (MERS-CoV) among Population in Saudi Arabia. Internat Arch Med. 2017:10 (254):1-12. doi:https://doi. org/10.3823/2524

26. Al-Mohaissen M. Awareness among a Saudi Arabian university community of Middle East respiratory syndrome coronavirus following an outbreak. East Mediter Health J. 2017:23 (5):351-60. PMID:28730588

27. Hoda J. Identification of information types and sources by the public for promoting awareness of Middle East respiratory syndrome coronavirus in Saudi Arabia. Health Educ Res. 2016:31 (1):12-23. doi:10.1093/her/cyvo61

28. Reusken CB, Farag EA, Haagmans BL, Mohran KA, Godeke G, Raj S, et al. Occupational exposure to dromedaries and risk for MERS-CoV infection, Qatar, 2013-2014. Emerg Infect Dis. 2015;21(8):1422-5. doi:10.3201/eid2108.150481

29. Alkot M, Albouq AM, Shakuri AM, Subahi SM. Knowledge, attitude, and practice toward MERS-CoV among primary healthcare workers in Makkah Al-Mukarramah: an intervention study. Int J Med Sci Pub Health. 2016:5:952. doi:10.5455/ijmsph.2016.15012016330 